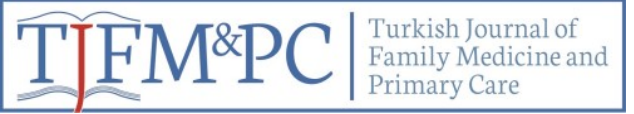

\title{
The Frequency and Some Causes of Anemia in Patients with Diabetes Mellitus with Normal Renal Function
}

\author{
Böbrek Fonksiyonları Normal Olan Diyabetes Mellitus Hastalarında Anemi Sıklı̆̆ı ve \\ Bazı Nedenleri
}

Elif Fatma Özkan Pehlivanoğlu ${ }^{* 1}$, Hüseyin Balcıoğlu ${ }^{2}$, Ŭgur Bilge ${ }^{2}$, Pınar Yıldız ${ }^{3}$, İlhami Ünlüoğlu ${ }^{2}$

\begin{abstract}
Introduction: Diabetes Mellitus (DM) is one of the most common chronic diseases worldwide according to World Health Organization reports. Anemia is common in patients with DM and anemia is a common hematological disorder in diabetic patients. In our study, we aimed to determine the anemia prevalence and the causes that affect anemia in patients with DM with normal renal function. Materials and Methods: Patients with DM who applied to Eskişehir Osmangazi University Medical Faculty Hospital (the clinics of Family Medicine and Internal Medicine) was included in our study and 229 patients with DM who were not diagnosed with renal dysfunction were included in our study within the last 6 months examinations. Laboratory results that were reviewed in the last 6 months were retrospectively screened and recorded. The hemoglobin $(\mathrm{Hb})$ limit values were evaluated as $12 \mathrm{grams} / \mathrm{deciliter}(\mathrm{g} / \mathrm{dl})$ in females and $13 \mathrm{~g} / \mathrm{dl}$ in males and patients with Hb levels below these values were accepted as anemia. The data obtained at the end of the study were analyzed by using SPSS package program. Results: DM patients with normal renal function were included in the study. \%25.8 (n=59) of patients had anemia. While $20.3 \%$ of the anemia was microcytic anemia, $79.7 \%$ was non-microcytic anemia (macrocytic and normocytic anemia). Iron deficiency was found in $57.1 \%(\mathrm{n}=32)$, while B12 deficiency was found in $11.8 \%(\mathrm{n}=7)$ and folic acid deficiency was found in $3.3 \%(\mathrm{n}=2)$ of patients with anemia. Iron deficiency was found in $9.9 \%(\mathrm{n}=14)$ of DM patients without anemia. Conclusion: Iron deficiency is the most diagnosed reason of anemia in DM patients. As the clinicians, we can provide early diagnosis and treatment of anemia in diabetic patients especially iron deficiency and we can improve the quality of life of patients and decrease morbidity and mortality.
\end{abstract}

Key words: Anemia; diabetes mellitus; diabetic complications.

\section{ÖZET}

Giriş: Diyabetes Mellitus Dünya Sağlık Örgütü raporlarına göre tüm dünyada en sık rastlanan kronik hastalıkların başında gelmektedir. Diyabetes Mellitus'u olan hastalarda anemi yaygındır ve anemi, diyabetik hastalarda sık görülen hematolojik bozukluklardandır. Çalışmamızla, böbrek fonksiyonları normal olan Diyabetes Mellitus hastalarında anemi sıklığını ve anemiyi etkileyen sebepleri belirlemeyi amaçladık. Materyal ve Metot: Eskişehir Osmangazi Üniversitesi Tıp Fakültesi Hastanesi Aile Hekimliği ve İç Hastalıkları polikliniklerine başvuran DM hastaları çalışmamıza dahil edilmiş olup, son 6 ay içinde yapılan muayenelerinde ve tetkiklerinde böbrek fonksiyon bozukluğu saptanmayan 229 DM hastası çalıșmamıza dahil edilmiștir. Son 6 ayda çalışılan laboratuvar sonuçları retrospektif olarak tarandı ve kaydedildi. Hemoglobin (Hb) sınır değerleri kadınlarda 12 gram / desilitre (g / dl), erkeklerde 13 g / dl olarak değerlendirildi ve bu değerlerin altında $\mathrm{Hb}$ seviyeleri olan hastalar anemi olarak kabul edildi. Çalışma sonunda elde edilen veriler SPSS paket programı kullanılarak analiz edilmiştir. Bulgular: Toplam 229 böbrek fonksiyonları normal olan DM hastası çalışmaya dahil edilmiştir. Anemilerin \%20.3'ü mikrositer anemi iken, \%79.7'si mikrositer olmayan anemiydi. Anemisi olan hastaların \%57.1'inde (n=32) demir eksikliği saptanırken, \%11.8'inde (n=7) B12 eksikliği, \%3.3'ünde $(\mathrm{n}=2)$ folik asit eksikliği saptanmıştır. Anemi saptanmayan DM hastalarının da \%9.9'unda (n=14) demir eksikliği olduğu belirlenmiştir. Sonuç: Demir eksikliği, DM hastalarında en sık teşhis edilen anemi nedenidir. Klinisyenler olarak, özellikle demir eksikliği olan diyabetik hastalarda erken dönemde anemi tanısı ve tedavisini sağlayabiliriz ve hastaların yaşam kalitesini iyileştirebilir, morbidite ve mortaliteyi azaltabiliriz.

Anahtar kelimeler: Anemi, diabetes mellitus, diabetik komplikasyonlar.

Received date / Geliş tarihi: 19.06.2019, Accepted date / Kabul tarihi: 19.05.2020

${ }^{1}$ Bolu Şehit Ziya Sarpkaya Göynük İlçe Devlet Hastanesi Bolu-TÜRKIYE.

${ }^{2}$ Eskișehir Osmangazi Ü nivesitesi Tıp Fakültesi Aile Hekimliği Anabilim Dalı Eskișehir-TÜRKIYYE.

${ }^{3}$ Eskişehir Osmangazi nivesitesi Tıp Fakültesi İç Hastalıkları Anabilim Dalı Eskişehir-TÜRKIYYE.

*Address for Correspondence / Yazıșma Adresi: Elif Fatma Özkan Pehlivanoğlu, Bolu Șehit Ziya Sarpkaya Göynük İlçe Devlet Hastanesi BoluTÜRKIYE.

E-mail: eliffatmaozkan@hotmail.com

Özkan Pehlivanoğlu EF, Balcığlu H, Bilge U, Yıldız P, Ünlüoğlu İ. The Frequency and Some Causes of Anemia in Patients with Diabetes Mellitus with Normal Renal Function. TJFMPC, 2020;14(3): 391-395.

DOI: $10.21763 /$ tjfmpc. 776312 


\section{INTRODUCTION}

Diabetes Mellitus (DM) is one of the most common chronic diseases worldwide according to World Health Organization (WHO) reports. ${ }^{1}$ The discovery of insulin and oral antidiabetic drugs significantly prolonged the survival of patients with diabetes. Therefore, the incidence of chronic complications due to the increase in diabetic life has increased. ${ }^{2}$ These complications are the most important cause of mortality and morbidity in diabetic patients. Major macrovascular complications include cardiovascular diseases leading to myocardial infarction and cerebrovascular diseases resulting in stroke. Microvascular complications are called nephropathy, retinopathy and neuropathy. ${ }^{3}$

Diabetes Mellitus (DM) is a chronic disease, and patients have a high chance of encountering chronic complications because of advances in treatment over the years. ${ }^{4}$ Anemia is common in patients with DM and anemia is a common hematological disorder in diabetic patients. ${ }^{5,6}$ Three factors have been proposed among the causes of early developing anemia in DM. Erythropoietin is produced from myofibroblasts in the renal tubulointerstistum. Tubulointersthesis damage is the first of the possible causes. Latter; autonomic dysfunction, and the third is associated with low hemoglobin concentrations due to the use of ACE inhibitors in patients. ${ }^{7}$ Many studies have shown that hypoxia-induced organ damage including cardiovascular events and mortality is associated with anemia. ${ }^{8}$ It has also been reported that anemia occurs mostly in DM patients with renal failure. In some studies, the incidence of anemia in DM patients without renal dysfunction was emphasized. ${ }^{9}$ Anemia increases the risk of developing diabetes and microvascular and macrovascular complications. Iron and erythropoietin deficiencies are the main causes of anemia in DM and diabetic nephropathy plays an important role in anemia. ${ }^{10}$

Anemia is known to intensify the risk of developing diabetes-related microvascular and macrovascular complications ${ }^{11}$. In this study, we aimed to determine the frequency of anemia and the factors that affect anemia in DM patients with normal renal function who applied to the outpatient clinics of Eskisehir Osmangazi University Medical Faculty Hospital.

\section{MATERIALS and METHODS}

The study was initiated by the researchers after the ethical approval by the Ethics Commission for Non-Interventional Studies of the Faculty of Medicine, Eskisehir Osmangazi University. Patients with DM who applied to the out-patient clinics of Medical Faculty Hospital Family Medicine and Internal Medicine Eskişehir Osmangazi University, were included in our study and 229 patients with DM who were not diagnosed with renal dysfunction were included in our study within the last 6 months. The glomerular filtration rate of the patients was determined by using Estimated Glomerular Filtration Rate calculation system to determine the renal dysfunction ${ }^{12}$. In the evaluation of kidney damage proteinuria, complete urine tests of patients were evaluated, and those with no proteinuria and those above the expected glomerular filtration rate values were considered normal. GFR values increase until the 18th month of life and reach adult values at age two; it becomes half or one-third of young adult values around 90 years old ${ }^{13}$. In the study of Melk et al. after the age of 40, it has been reported that GFR decreases 10 $\mathrm{ml} / \mathrm{min}$ per decade ${ }^{14}$. The questionnaire form which was prepared by the researchers was applied to the participants by face to face interview method. The questionnaire form included 15 questions that questioned the participants' sociodemographic characteristics, duration of diabetes, current forms of treatment, complication conditions, and additional diseases. Complication conditions data had taken from their patient files. Red blood cells, hemoglobin, hematocrit, white blood cells, platelet counts and mean corpuscular volume (MCV) are given in the routine laboratory results of our hospital. Laboratory results that were reviewed in the last 6 months were retrospectively screened and recorded. The hemoglobin $(\mathrm{Hb})$ values were evaluated as 12 grams/deciliter $(\mathrm{g} / \mathrm{dl}$ ) in females and $13 \mathrm{~g} / \mathrm{dl}$ in males and patients with $\mathrm{Hb}$ levels below these values were accepted as anemia. ${ }^{15}$ According to MCV values, anemias are classified as microcyte, normocyte, and macrocyte ${ }^{16}$. MCV allows us to classify anemia as microcytic (MCV $<82 \mathrm{fl})$, normocytic $(82-98 \mathrm{fl})$ or macrocytic $(\mathrm{MCV}>98 \mathrm{fl})^{17}$. The lower limit of vitamin B12 vitamin levels were $200 \mathrm{pg} / \mathrm{mL}$ and the lower limit of folate levels was considered as $4 \mathrm{ng} /$ $\mathrm{mL} .{ }^{18,19}$ The level of serum ferritin is the strongest test used to evaluate the deficiency of iron. The limit value was $12-15 \mathrm{mg} / 1$. This value was found to be $50 \mathrm{mg} / 1$ if there was an accompanying chronic disease. ${ }^{15}$ In our study, the limit value of ferritin was evaluated as $50 \mathrm{mg} / \mathrm{l}$ in iron deficiency evaluation in DM patients. The data obtained at the end of the study were analyzed by using SPSS package program. Pearson's ChiSquare, Yates Chi-Square, Fisher's Exact ChiSquare tests were used to analyze the data. The level of statistical significance was accepted as $\mathrm{p}$ $<0.05$. 


\section{RESULTS}

A total of 229 patients with normal renal function were included in the study. Of the participants, $63.3 \%(\mathrm{n}=145)$ were female and $36.7 \%(\mathrm{n}=84)$ were male. The mean age was $54.6 \pm 11.8$ years. Anemia was detected in $25.8 \%(n=59)$ of all participants, $74.6 \%(\mathrm{n}=44)$ of women with anemia and $25.4 \%(n=15)$ of them were male. In terms of education, while $1.7 \%(n=4)$ of the participants were only literate, $24.0 \%(\mathrm{n}=55)$ were primary school, 38\% $(\mathrm{n}=87)$ were secondary school, $23.6 \%(\mathrm{n}=54) 11.8(\mathrm{n}=27)$ were university graduates and $0.9 \%(n=2)$ were graduates of postgraduate education. $83.8 \%(n=192)$ of the participants were married and $16.2 \%(\mathrm{n}=37)$ stated marital status as single. $\% 25.8 \quad(n=59)$ of patients had anemia. While $20.3 \%$ of the anemia was microcytic anemia, $79.7 \%$ was non-microcytic anemia (macrocytic and normocytic anemia). Iron deficiency was found in $57.1 \%(\mathrm{n}=32)$ of patients with anemia, while B12 deficiency was found in $11.8 \%(\mathrm{n}=7)$ and folic acid deficiency was found in $3.3 \%(\mathrm{n}=2)$. Iron deficiency was found in $9.9 \%$ $(n=14)$ of DM patients without anemia. There was no statistically significant difference between retinopathy and neuropathy complications and anemia cases $(p=0.250, p=0.156)$. Anemia was significantly lower in smoking DM patients than in non-smokers $(\mathrm{p}<0.001)$.

When $\mathrm{HbA} 1 \mathrm{c}$ levels and $\mathrm{Hb}$ and Hematocrit (Htc) were examined, there was no significant difference was found between $\mathrm{HbAlc}$ and $\mathrm{Hb}$ levels statistically, but there was a statistically significant difference between $\mathrm{HbAlc}$ and Htc levels $(\mathrm{p}=0.098, \mathrm{p}=0.010)$.

There was no statistically significant relationship between anemia and hypertension, hyperlipidemia and obesity in DM patients and this relationship is shown in Table 1.

\begin{tabular}{|c|c|c|c|}
\hline \multicolumn{4}{|c|}{ Table 1. The relationship between anemia and chronic diseases in DM patients. } \\
\hline Chronic Diseases & Anemia (+) & Anemia (-) & p value \\
\hline $\begin{array}{c}\text { Hypertension } \\
(\mathbf{N}=\mathbf{8 3})\end{array}$ & $19(22.9 \%)$ & $64(\% 77.1)$ & 0.554 \\
\hline $\begin{array}{c}\text { Hyperlipidemia } \\
(\mathbf{n}=\mathbf{4 2})\end{array}$ & $8(19.0 \%)$ & $34(81.0 \%)$ & 0.365 \\
\hline $\begin{array}{c}\text { Obesity } \\
(\mathbf{n}=\mathbf{1 6})\end{array}$ & $3(18.7 \%)$ & $13(81.3 \%)$ & 0.712 \\
\hline
\end{tabular}

*Chi-Square Test

Among DM patients who used metformin, anemia was significantly higher than DM patients without metformin $(p=0.049)$. When the relationship between sulfonylurea and insulin use was examined, no statistically significant difference was found between them and Table 2 shows the relationship between them. There was no statistically significant difference between metformin use and vitamin b12 deficiency $(p=0.656)$.

\begin{tabular}{|c|c|c|c|}
\hline \multicolumn{2}{|c|}{ Table 2. Relationship between anemia and treatment agents in DM patients. } \\
\hline Treatment Agents & Anemia (+) & Anemia (-) & p value \\
\hline $\begin{array}{c}\text { Metformin } \\
(\mathbf{n}=\mathbf{2 0 7})\end{array}$ & $49(23.6 \%)$ & $158(76.4 \%)$ & 0.049 \\
\hline $\begin{array}{c}\text { Sulphonylureas } \\
(\mathbf{n}=\mathbf{6 9})\end{array}$ & $16(23.2 \%)$ & $53(76.8 \%)$ & 0.674 \\
\hline $\begin{array}{c}\text { İnsulin } \\
(\mathbf{n}=62)\end{array}$ & $16(25.8 \%)$ & $46(74.2 \%)$ & 0.559 \\
\hline
\end{tabular}

*Chi-Square Test

\section{DISCUSSION}

Anemia is often associated with DM and is known to increase the risk of developing diabetes- associated microvascular and macrovascular complications. Iron and / or erythropoietin 
deficiencies are the main causes of anemia in diabetes and diabetic kidney disease plays an important role in the formation of anemia. Patients with diabetes should be screened for anemia with other risk factors and anemia corrected to improve overall clinical outcomes. It should be aimed to provide a comprehensive overview and algorithm for the treatment of appropriate anemia in patients with diabetes. ${ }^{10} \mathrm{He}$ et al. reported that anemia was found to be significantly higher in DM patients with diabetic retinopathy (DR) and diabetic neuropathy $(\mathrm{DN})$ than in patients with non-DR and non-DM. ${ }^{20}$ In our study, there was no statistically significant difference between DR and DN with anemia.

Smoking in healthy individuals results in an increase in $\mathrm{Hb}$ levels mediated by carbon monoxide exposure. Carbon monoxide converts $\mathrm{Hb} \mathrm{Hi}$ to carboxyhemoglobin (HbCO), which has a significantly reduced oxygen-carrying capacity. $\mathrm{HbCO}$ causes a shift to the left of the dissociation curve and leads to a decrease in the ability of $\mathrm{Hb}$ to deliver oxygen to the tissues. To compensate for this reduced oxygen delivery, smokers have a higher level of $\mathrm{Hb}$ than nonsmokers. Average $\mathrm{Hb}$ and $\mathrm{HbCO}$ levels are increasing with the number of cigarettes consumed per day. Smokers who consume 40 or more cigarettes per day have $\mathrm{Hb}$ levels higher than the others. In addition to the number of cigarettes smoked per day, chronic exposure to $\mathrm{HbCO}$ is also associated with the development of polycythemia. ${ }^{21}$ In our study, we think that this mechanism is effective in the etiopathogenesis of DM patients who have higher levels of $\mathrm{Hb}$ than non-smokers.

In some studies, vitamin B12 deficiency has been reported in metformin-treated type $2 \mathrm{DM}$ patients. ${ }^{22,23}$ In their study, Raizada et al. found that vitamin B12 deficiency was higher in DM patients using metformin than in the normal population. ${ }^{24}$ In our study, we found a statistically significant high difference between the use of metformin and anemia. But on the other hand, there was no statistically significant difference between metformin use and vitamin B12 deficiency. We think that limitation of the sample size or previous vitamin use of patients may be effective in determining this result. Therefore, we think that the follow-up of DM patients should be followed in terms of anemia during metformin use.

Treatment of anemia not only reduces fatigue but increases also exercise tolerance and improves quality of life, but also leads to a reduction in mortality and hospitalization due to congestive heart failure. Early diagnosis and treatment of anemia in patients with DM may improve quality of life and decrease morbidity and mortality. ${ }^{25}$

\section{CONCLUSION}

Iron deficiency is the most diagnosed reason of anemia in Diabetes Mellitus patients. As the clinicians, we can provide early diagnosis and treatment of anemia in diabetic patients especially iron deficiency and we can improve the quality of life of patients and decrease morbidity and mortality.

\section{REFERENCES}

1. Olgun N, Yalın $H$, Gülyüz Demir $H$. Diagnosis And Risk Determination Of Diabetes Dealing With Diabetes. Turkish Family Physcian, 2011; 2(2): 36-44.

2. Gücük S, Boztas G. The Effects of Family Medicine Practice on Diabetic Patients' Follow up. Konuralp Medical Journal 2013; 5(2):12-16.

3. Forbes JM, Cooper ME. Mechanisms of diabetic complications. Physiol Rev.2013; 93: $137-188$.

4. Sezgin H, Çınar S. Follow-up of Patients with Type 2 Diabetes Via Cell Phone: Randomized Controlled Trial. Journal of Marmara University Institute of Health Sciences 2013;3(4):173-183.

5. Chung JO, Park SY, Cho DH, Chung DJ, Chung MY. Anemia, bilirubin, and cardiovascular autonomic neuropathy in patients with type 2 diabetes. Medicine (Baltimore), 2017; 96(15): 6586.

6. Thomas MC, MacIsaac RJ, Tsalamandris C, Molyneaux L, Goubina I, Fulcher G, et al. The burden of anaemia in type 2 diabetes and the role of nephropathy. A cross-sectional audit. Nephrol Dial Transplant. 2004;19:1792-7.

7. White KE, Bilous RW. Type 2 diabetic patients with nephropathy Show structural - functional relationships that are similar to type 1 disease. J Am Soc Nephrol.2000; 11: 1667 - 1673.

8. Thomas MC. Anemia in diabetes: marker or mediator of microvascular disease? Nat Clin Pract Nephrol. 2007;3:20-30.

9. A case-control study of prevalence of anemia among patients with type 2 diabetes. Antwi-Bafour et al. Journal of Medical Case Reports. 2016; 10:110.

10. Sahay M, Kalra S, Badani R, Bantwal G, Bhoraskar A, Das AK, Dhorepatil B, et al. Diabetes and Anemia: International Diabetes Federation (IDF)-Southeast Asian Region (SEAR) position statement. Diabetes \& Metabolic Syndrome: Clinical Research \& Reviews, 2017; 11: 685-695.

11. Sahay M, Kalra S, Badani R, Bantwal G, Bhoraskar A, Das AK, Dhorepatil B, et al. 
Diabetes Metab Syndr. 2017 Dec;11 (2): 685-95.

12. Chiu WC, Lai YR, Cheng BC, Huang CC, Chen JF, Lu CH. HbA1C Variability Is Strongly Associated with Development of Macroalbuminuria in Normal or Microalbuminuria in Patients with Type 2 Diabetes Mellitus: A Six-Year Follow-Up Study. Biomed Res Int. 2020; 2020:7462158.

13. Summerville DA, Clinton SP, Treves ST. The use of radiopharmaceuticals in the measurement of glomerular filtration rate: A review. In: Freeman LM ed. Nuclear Medicine Annual. New York: RavenPress; 1990:191-221

14. Melk A, Ramassar V, Helms LM, et al. Telomere shortening in kidneys with age. J Am Soc Nephrol 2000;11(3): 444-53.

15. Türk Hematoloji Derneği. Yetişkinde Demir Eksikliği Tanı Ve Tedavi Kılavuzu. Ulusal Tedavi Kilavuzu. 2011; 23-24. http://www.thd.org.tr/thdData/Books/94/b olum-iii-yetiskinde-demir-eksikligi-tanive-tedavi-kilavuzu.pdf Son Erişim Tarihi: 18/06/2019.

16. Glader B. Anemias, In: Behrman R, Kliegman R, Jenson $H$. eds. Nelson Textbook of Pediatrics. 17th ed. Pennsylvania: Saunders, 2004: 1604-6.

17. Jose Antonio Moreno Chulilla, Maria Soledad Romero Colás, Martín Gutiérrez Martín. Classification of anemia for gastroenterologists. World J Gastroenterol 2009; 15: 4627-37.

18. Honzik T, Adamovicova M, Smolka V, Magner M, Hruba E, Zeman J. Clinical presentation and metabolic consequences in 40 breastfed infants with nutritional vitamin $\mathrm{B}(12)$ defi ciency. What have we learned? Eur J Paediatr Neurol. 2010; 14: 488-95.

19. Koc A, Kocyigit A, Soran M, Demir N, Sevinc E, Erel $\mathrm{O}$ et al. High frequency of maternal vitamin B12 defi ciency as an important cause of infantile vitamin B12 defi ciency in Sanliurfa province of Turkey. Eur J Nutr 2006; 45: 291-7.

20. He BB, Xu M, Wei L, Gu YJ, Han JF, Liu YX, Bao YQ, Jia WP. Relationship between Anemia and Chronic Complications in Chinese Patients with Type 2 Diabetes Mellitus. Arch Iran Med. 2015;18(5):277-83.

21. Leifert JA. Anaemia and cigarette smoking. Int J Lab Hematol. 2008;30(3):177-84.

22. Calvo Romero JM, Ramiro Lozano JM. Vitamin $\mathrm{B}(12)$ in type 2 diabetic patients treated with metformin. Endocrinol Nutr. 2012;59:487-90.

23. Nervo $M$, Lubini A, Raimundo FV, Faulhaber GA, Leite C, Fischer LM, et al. Vitamin B12 in metformin-treated diabetic patients: A cross-sectional study in Brazil. Rev Assoc Med Bras. 2011;57:46-9.

24. Raizada N, Jyotsna VP, Sreenivas V, Tandon N. Serum Vitamin B12 Levels in Type 2 Diabetes Patients on Metformin Compared to those Never on Metformin: A Cross-sectional Study. Indian J Endocrinol Metab. 2017;21(3):424-428.

25. McGill JB, Bell DSH. Diyabette anemi ve eritropoetinin rolü. Journal of Diabetes and its Complition. 2006; 2(4): 200-212. 